J. Perinat. Med. $13(1985) 31$

\section{Catecholamines in arterial and venous umbilical blood: placental extraction, correlation with fetal hypoxia, and transcutaneous partial oxygen tension}

\author{
R. Paulick, E. Kastendieck, H. Wernze
}

Department of Obstetrics and Gynecology, Department of Internal Medicine, University Würzburg, F. R. Germany

\section{Introduction}

Investigations performed in animal experiments $[6,7,16,17,19]$ as well as in man $[2,3,9,10,18$, $20,25]$ suggest that fetal hypoxia is associated with an increase in circulating catecholamines due to sympathoadrenal stimulation. The correlation between catecholamines and cardiovascular, respiratory, and metabolic changes as determined during intrapartum fetal monitoring by means of cardiotocography (CTG), fetal blood gas analysis, and measurement of the transcutaneous partial oxygen tension $\left(\mathrm{tcpO}_{2}\right)$ has not yet been exhaustively investigated. The effect of fetal hypoxia on the dopamine concentration in cord blood likewise has not been explored.

These gaps in our knowledge are attributable to some extent to methodological factors. The older (fluorimetric) tests, which require blood volumes of $15-20 \mathrm{ml}$, are restricted to the detection of epinephrine (E) and norepinephrine (NE) in mixed cord blood $[3,22]$ or venous umbilical blood [18, 23 ], and some studies only measured total catecholamines $[2,20]$ without further differentiation. In contrast, the radioenzymatic single-isotope technique $[8,29]$ allows the specific measurement of $\mathrm{E}, \mathrm{NE}$ and the third catecholamine; dopamine (D), in 0.1-0.2 ml plasma. With the advent of this method it has become possible to reassess the following questions of clinical interest:

1. To what extent are free catecholamines, varying over a wide range from normal to exceptionally

\section{Curriculum vitae}

RENE PAULICK, $M$. D., was born in January, 1956 in Hannover, Germany. Medical studies in Würzburg from 1974 to 1980. He is at present assistent at the Department of Obstetrics and Gynecology, University of Würzburg (Head: Prof. Dr. K.-H. WULF). Chief area of interest: Fetal and neonatal physiology, gynecological oncology.

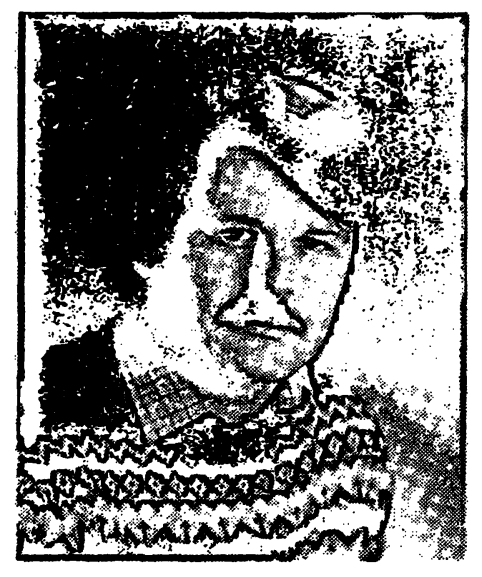

high values, extracted across the human placenta?

What interrelationship exists between the extraction rates of $\mathrm{NE}, \mathrm{E}$, and $\mathrm{D}$ ?

2. How are fetal hypoxia, acidosis, changes in fetal heart rate (FHR), and postpartum fetal distress associated with the catecholamine levels in fetal plasma?

3. Is an increased secretion of catecholamines in the human fetus accompanied by a fall in tcpO $\mathrm{O}_{2}$, as has previously been suggested though only on the basis of animal experiments [16, $19,28]$ ?

\section{Methods}

The patients in our study comprised 34 parturient women aged 19-34 years who after essentially 
uncomplicated pregnancies (duration of pregnancy 36-41 weeks) were delivered vaginally (30 spontaneous births, 4 vacuum extractions). The birth weights ranged from $2450-4460 \mathrm{~g}$. Free catecholamine concentrations were determined separately in arterial and venous umbilical blood following immediate clamping of the cord, and in samples of maternal blood obtained immediately after delivery from the brachial vein.

After collection the blood was at once transferred into chilled polypropylene tubes to which had been added, as anticoagulant and antioxidant, $50 \mu \mathrm{l}$ of a solution containing $76 \mathrm{mg} / \mathrm{ml}$ EGTA (ethyleneglycol-bis-( $\beta$-aminoethyl ether) $N, N, N^{\prime}$ tetraacetic acid) and $48 \mathrm{mg} / \mathrm{ml}$ reduced glutathione. In some of the later experiments, lithiumheparin tubes (SARSTEDT No. 36 377) were used since comparative studies had shown that catecholamine concentrations can be measured with equal accuracy in heparinized plasma and antioxidant-containing heparinized plasma, but not in EDTA-containing plasma. It is important however that tubes are placed on ice without delay [36]. Hemolyzed samples were discarded. After centrifugation for 10 minutes $(4000 \mathrm{rpm})$ at +2 to $+4{ }^{\circ} \mathrm{C}$, the plasma was kept frozen at $-25^{\circ} \mathrm{C}$ until assayed.

The concentrations of free NE, E, and D were assayed radioenzymatically using a modified and shortened version of the method of PEULER and JOHNSON [8, 29, 36]. The sensitivity of the method is below $1 \mathrm{pg} / \mathrm{ml}$ for $\mathrm{NE}, \mathrm{E}$, and $\mathrm{D}$, with intra-assay and inter-assay coefficients of variation of approx. $3 \%$ and $10 \%$, respectively.

The acid-base balance and blood gases were assessed with the TECHNICON Gas Analyzer. The base deficit in the extracellular fluid was calculated nomographically by the method of SIGGAARDANDERSEN from the $\mathrm{pH}$ and $\mathrm{pCO}_{2}$ in the umbilical artery, hemoglobin concentration $5 \mathrm{~g} \%$ [33].

For interpretation of the cardiotocograph (CTG) tracings, the deceleration areas obtained during the last hour antepartum were measured planimetrically in $\mathrm{cm}^{2} / \mathrm{h}$ (chart speed: $1 \mathrm{~cm} / \mathrm{min} ; \mathrm{FHR}$ amplitude: $1 \mathrm{~cm}=20 \mathrm{bpm})$. 'The baseline heart rate was determined every 2 minutes, followed by calculation of mean values.
In 22 parturient women the fetal $t c \mathrm{pO}_{2}$ was continuously monitored with an oxygen electrode (TRANSOXODE/Hellige) during the late first stage and the second stage of labor. At the same time, the catecholamine concentrations in the umbilical vessels were measured in 14 patients. The electrode was applied to the fetal scalp by means of a self-adhesive tissue glue (HISTO-ACRYL, Braun Melsungen). The temperature of the electrode was adjusted to $44^{\circ} \mathrm{C}$. After attainment of a stable level, the $\mathrm{tcpO}_{2}$ was recorded for $92 \pm 71$ (SD) minutes on average. The mean $\mathrm{tcpO}_{2}$ values determined at 10-minute intervals were used to calculate during the last hour before delivery the overall means. By simultaneously recording the relative local skin perfusion, distinct artefacts could be identified and excluded [14].

The statistical analysis and significance calculations were performed at the Computer Center of Würzburg University (Dr. I. HAUBITZ). The correlation coefficients were calculated using either the Spearman rank correlation test (when there was no normal distribution) or the Kendall rank correlation test (when 'ties' were present).

\section{Results}

3.1 Catecholamine concentrations in arterial and venous cord blood; placental catecholamine extraction: The free catecholamine levels measured in arterial and venous cord blood may vary substantially (Fig. 1). The mean NE concentration was $10,200 \mathrm{pg} / \mathrm{ml}$ (range $1,500-74,100 \mathrm{pg} / \mathrm{ml}$ ) in arterial cord blood and $2,650 \mathrm{pg} / \mathrm{ml}$ (range 200 $30,700 \mathrm{pg} / \mathrm{ml}$ ) in venous cord blood. The concentrations of $\mathrm{E}$ in arterial and venous cord blood were $1,120 \mathrm{pg} / \mathrm{ml}$ (range $140-4,030 \mathrm{pg} / \mathrm{ml}$ ) and $280 \mathrm{pg} / \mathrm{ml}$ (range $25-1,790 \mathrm{pg} / \mathrm{ml}$ ), respectively.

The concentrations of circulating free $D$ approximated $130 \mathrm{pg} / \mathrm{ml}$ (range $30-660 \mathrm{pg} / \mathrm{ml}$ ) in arterial cord blood, and $70 \mathrm{pg} / \mathrm{ml}$ (range $15-320 \mathrm{pg} / \mathrm{ml}$ ) in venous cord blood.

The placental catecholamine extraction rate (ER), calculated from the concentrations in the umbilical 


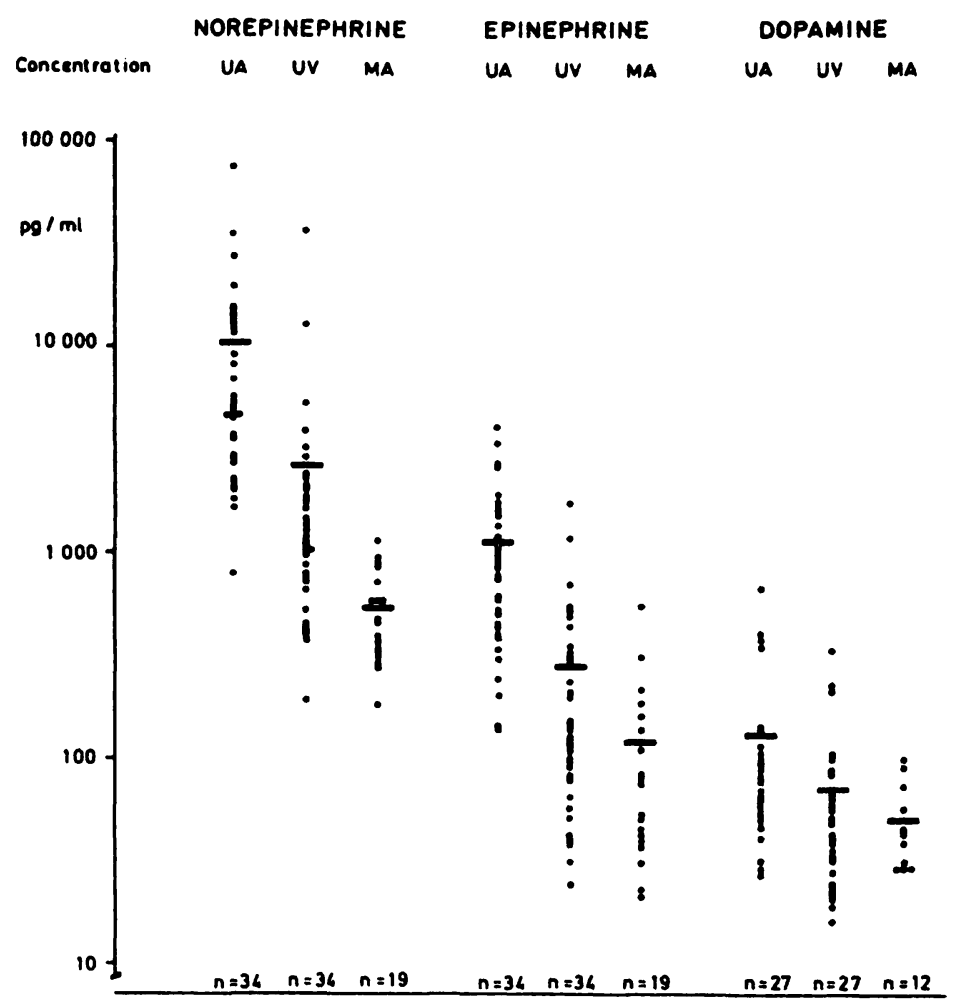

Fig. 1. Concentrations of free NE, E and D in the umbilical artery (UA), umbilical vein (UV) and in maternal venous (brachial vein) blood (MA) at the time of delivery.

Epinephrine

rate of extraction

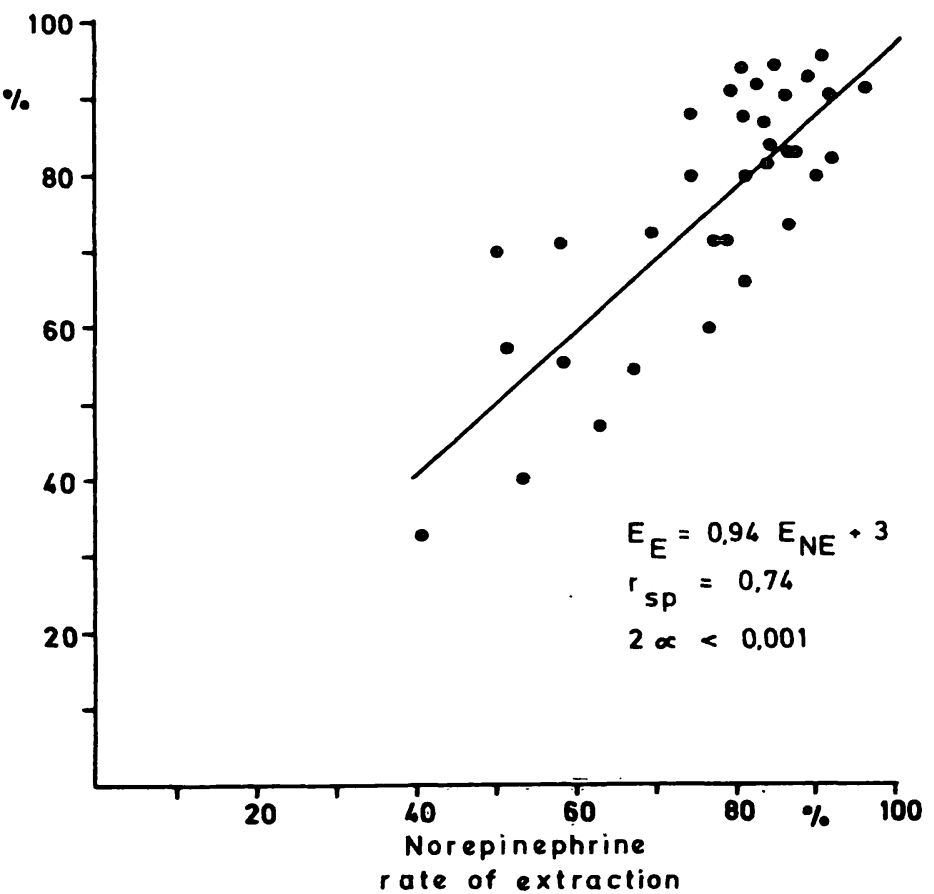

Fig. 2. Correlation between the extraction rates of $E$ $\left(E R_{E}\right)$ and $N E\left(E R_{N E}\right)$ during placental passage. Extraction rates vary between $35 \%$ and $95 \%$. A highly significant correlation is demonstrated. There is no difference between the regression line and the line of identity. artery $\left(\mathrm{C}_{\mathrm{ua}}\right)$ and umbilical vein $\left(\mathrm{C}_{\mathrm{uv}}\right)$ according to the formula

$E R=\frac{C_{u a}-C_{u v}}{C_{u a}} \cdot 100$

was established as $77 \pm 14 \%$ (range 41-96) for $\mathrm{NE}, 76 \pm 16 \%$ (range $33-96$ ) for $\mathrm{E}$, and $33 \pm 25 \%$ (range 24-99) for D.

There was a significant correlation between the extraction rates of $\mathrm{E}$ and NE (Fig. 2).

The umbilical arteriovenous difference in NE and $\mathrm{E}$ concentration rose in proportion to the arterial catecholamine concentration (Fig. 3).

\subsection{Catecholamine concentrations in maternal} blood: At the time of delivery, the mean free $\mathrm{NE}$ concentrations in the maternal venous blood were $540 \mathrm{pg} / \mathrm{ml}$ (range 180-1,120 pg/ml) (Fig. 1). In the majority of the patients, the NE levels thus exceeded the normal range of $100-450 \mathrm{pg} / \mathrm{ml}$ that had been determined using the same method in normotensive male and female subjects under conditions of rest [36].

The concentrations of free $\mathrm{E}$ in the maternal blood, $120 \mathrm{pg} / \mathrm{ml}$ (range $20-550 \mathrm{pg} / \mathrm{ml}$ ), were likewise

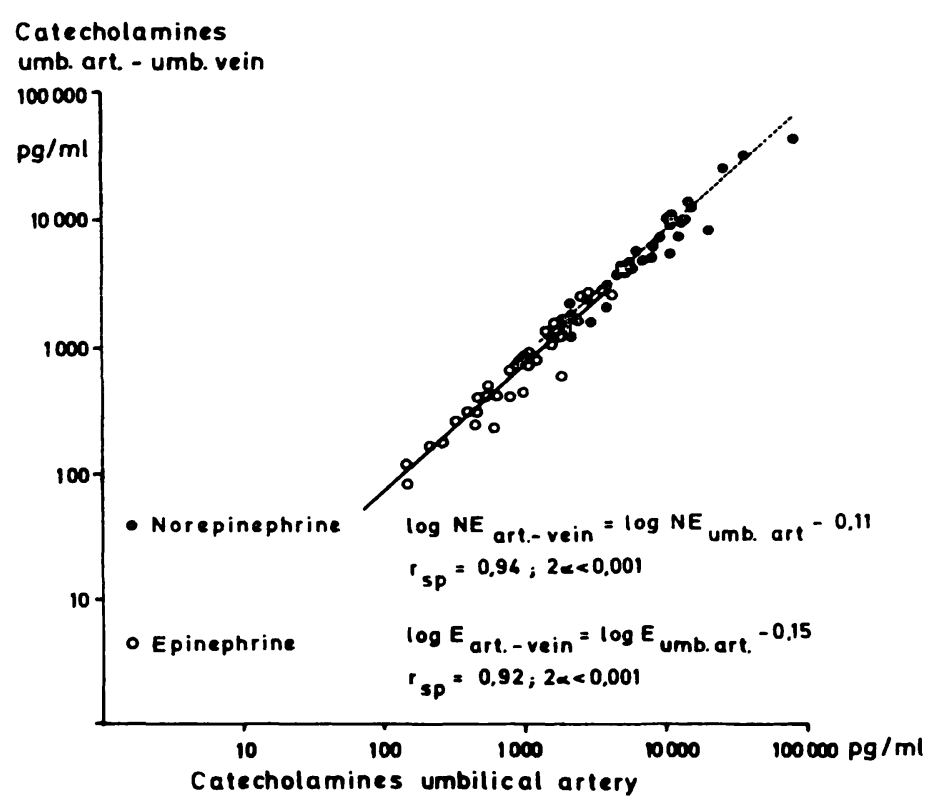

Fig. 3. Correlation between the arterio-venous concentration difference of $\mathrm{E}$ and $\mathrm{NE}$ and arterial concentrations. A linear relationship is demonstrated in the range below $4.000 \mathrm{pg} / \mathrm{ml}$ for $\mathrm{E}$ and $74.000 \mathrm{pg} / \mathrm{ml}$ for $\mathrm{NE}$, suggesting that the placental catecholamine extraction does not reach full saturation. 
increased over the normal E levels (20-95 pg/ml). In contrast, the mean concentrations recorded for free $\mathrm{D}, 50 \mathrm{pg} / \mathrm{ml}$ (range $30-100 \mathrm{pg} / \mathrm{ml}$ ), were fairly unchanged compared to the normal range of $10-70 \mathrm{pg} / \mathrm{ml}$.

2.3 Catecholamines and fetal hypoxia: As shown in Figs. 4 and 5, there was a highly significant relationship between the umbilical arterial $\mathrm{NE}$ levels, neonatal status (as assessed by the 1-minute APGAR score), and metabolic acidosis (determined by $\mathrm{pH}$ and base deficit). In some cases, the $\mathrm{NE}$ concentrations in the fetal blood were exceedingly high when associated with low Apgar scores and increasing metabolic acidosis. Analysis of the FHR in the last hour preceding delivery also revealed a significant relation between the area of deceleration, the baseline FHR, and the umbilical arterial $\mathrm{NE}$ concentrations. The fetal NE concentrations were found to rise as the deceleration area and baseline FHR increased (Fig. 6).

Fig. 7 gives a more detailed description of the correlation that exists between deceleration area, fetal tachycardia, and arterial NE concentration. It is seen that an increase of the deceleration area $\left(>15 \mathrm{~cm}^{2} / \mathrm{h}\right)$ is not associated with elevated $\mathrm{NE}$ levels. A significant rise in the fetal arterial $\mathrm{NE}$

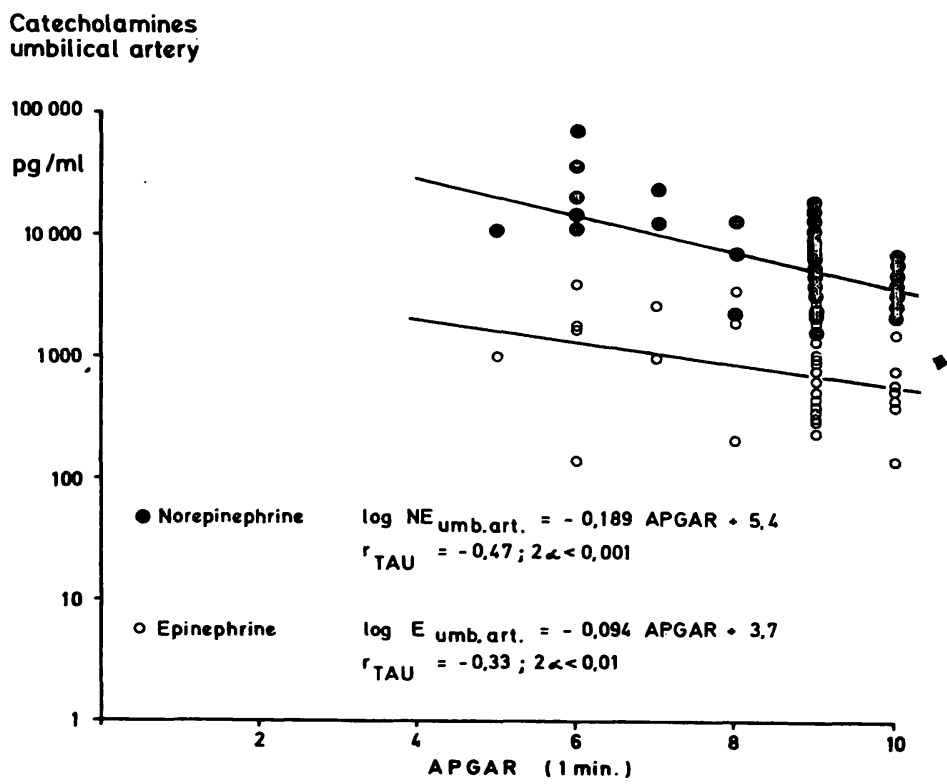

Fig. 4. Correlation between the 1-minute APGAR score and $N E$ and $E$ concentrations in the umbilical artery. Low APGAR scores are associated with increased catecholamine concentrations.
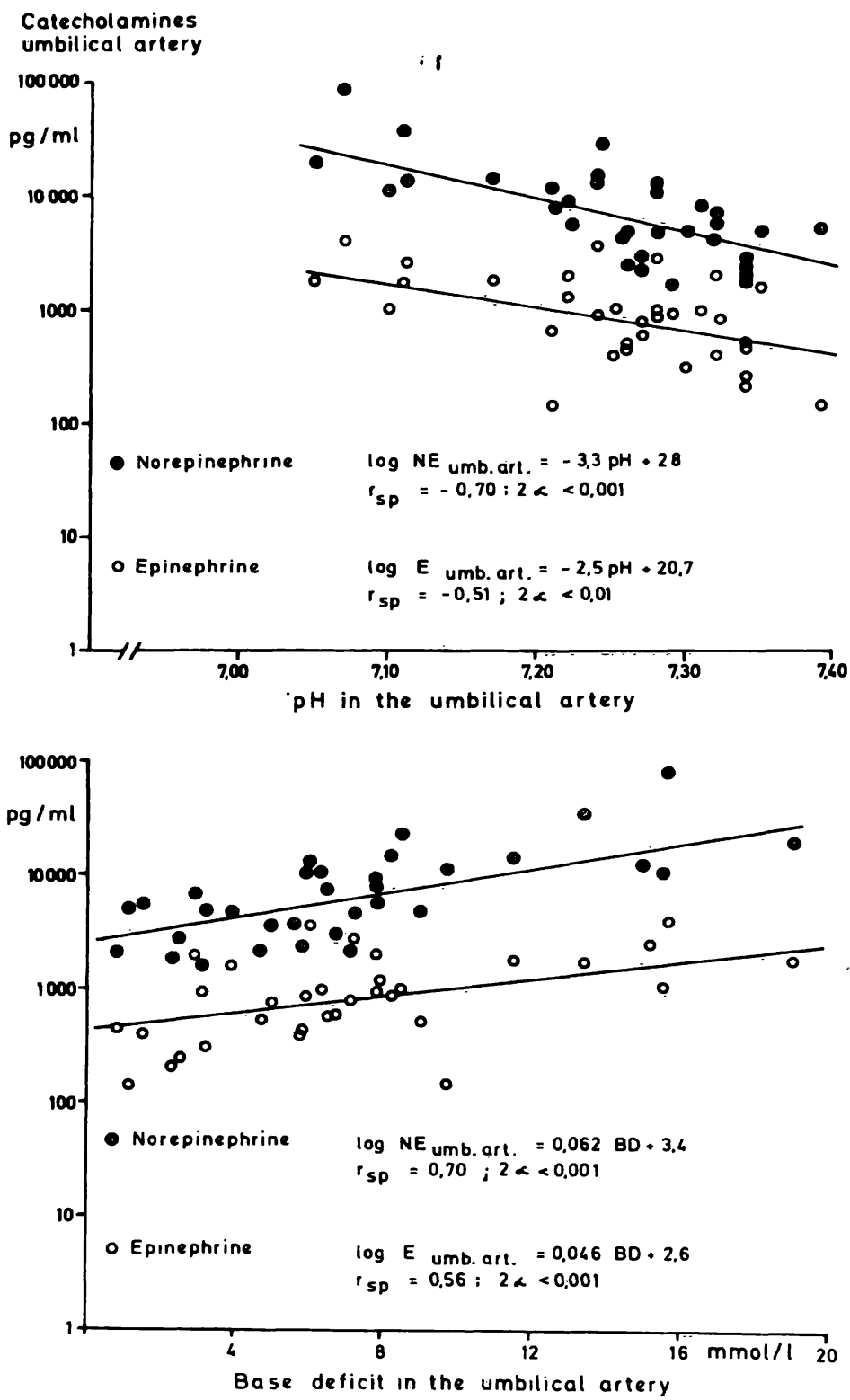

Fig. 5. Correlation between fetal arterial NE and $E$ concentrations and metabolic acidosis measured by the $\mathrm{pH}$ and base deficit in the umbilical artery. Catecholamine concentrations start to rise with increasing metabolic acidosis.

concentrations only occurs when tachycardia $(>150 \mathrm{~b} / \mathrm{min})$ supervenes.

Fetal arterial $\mathrm{E}$ concentrations as an indicator of enhanced release of the hormone from the adrenal medulla in conditions of stress, also demonstrate good correlations with the fetal parameters, although the correlation coefficients were lower than for NE (Figs. 4-6).

Unlike $N E$ and $E$ concentrations, the $D$ levels in the umbilical vessels were affected by fetal hypoxia to a minor degree, only. 

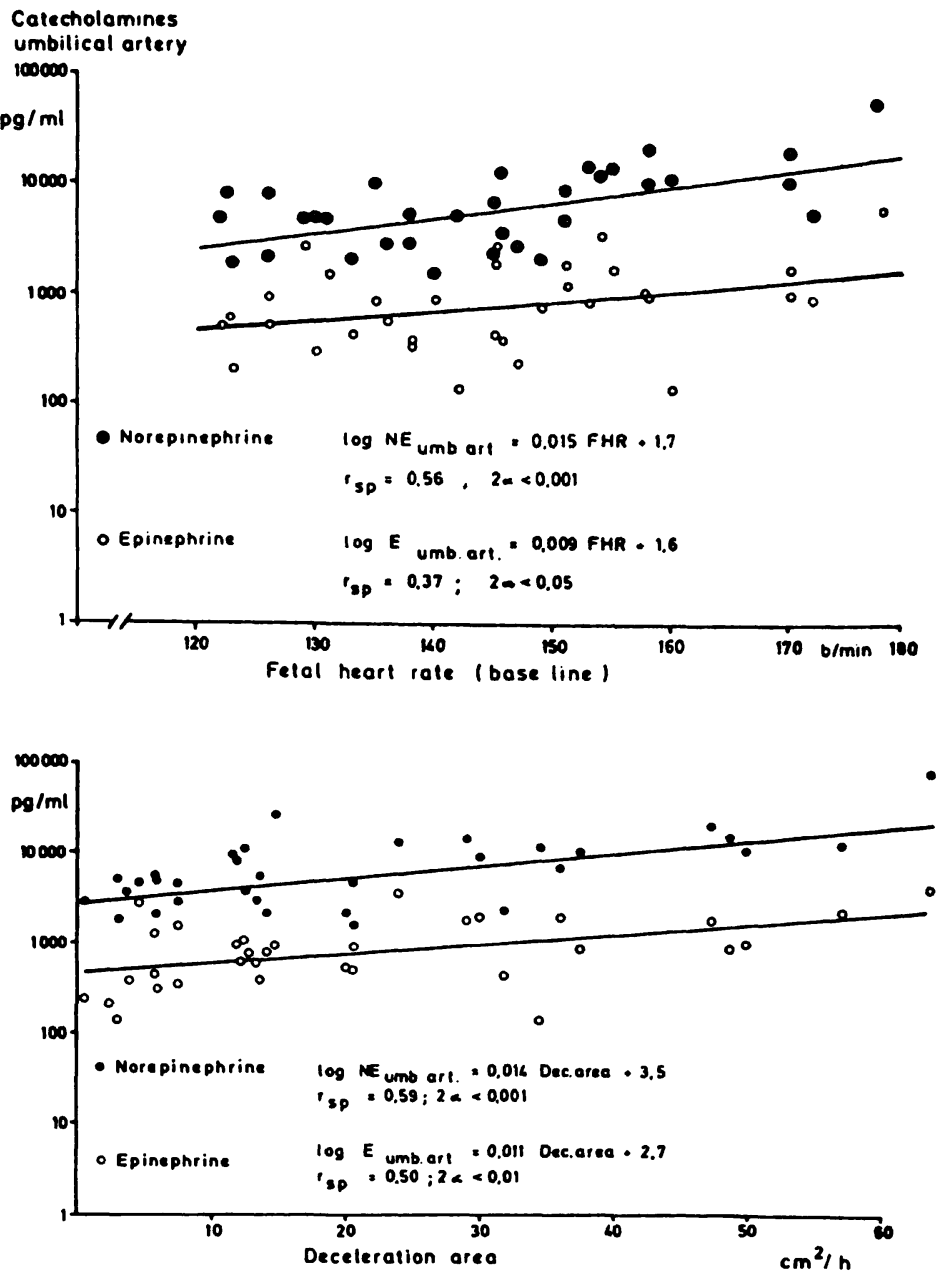

Fig. 6. Correlation between fetal arterial NE and $E$ concentrations and baseline FHR and deceleration area during the last hour antepartum. Catecholamine concentrations rise with increasing deceleration area and baseline FHR.

3.4 Catecholamines, transcutaneous $\mathrm{pO}_{2}$, and transcutaneous-arterial $\mathrm{pO}_{2}$ difference: Fig. 8 illustrates the $\mathrm{tcpO}_{2}$ values recorded during the 2 hours preceding parturition. They differ widely, ranging between $0-25 \mathrm{~mm} \mathrm{Hg}$ and showing a tendency to decrease before delivery.

In Fig. 9, the mean $\mathrm{tcpO}_{2}$ measured during the last hour before delivery is plotted against the NE concentration in the umbilical artery. There was a significant inverse relation with $\mathrm{NE}$ concentrations rising as $\mathrm{tcpO}_{2}$ values decreased. No correlation could be detected between arterial $E$ levels and the $\mathrm{tcpO}_{2}$.

In most of the cases (70\%), the $\mathrm{tcpO}_{2}$ measured during the last hour before delivery was lower than the umbilical artery $\mathrm{pO}_{2}$. This transcutaneousarterial $\mathrm{pO}_{2}$ difference (tc-art $\mathrm{pO}_{2}$-d) was depen-

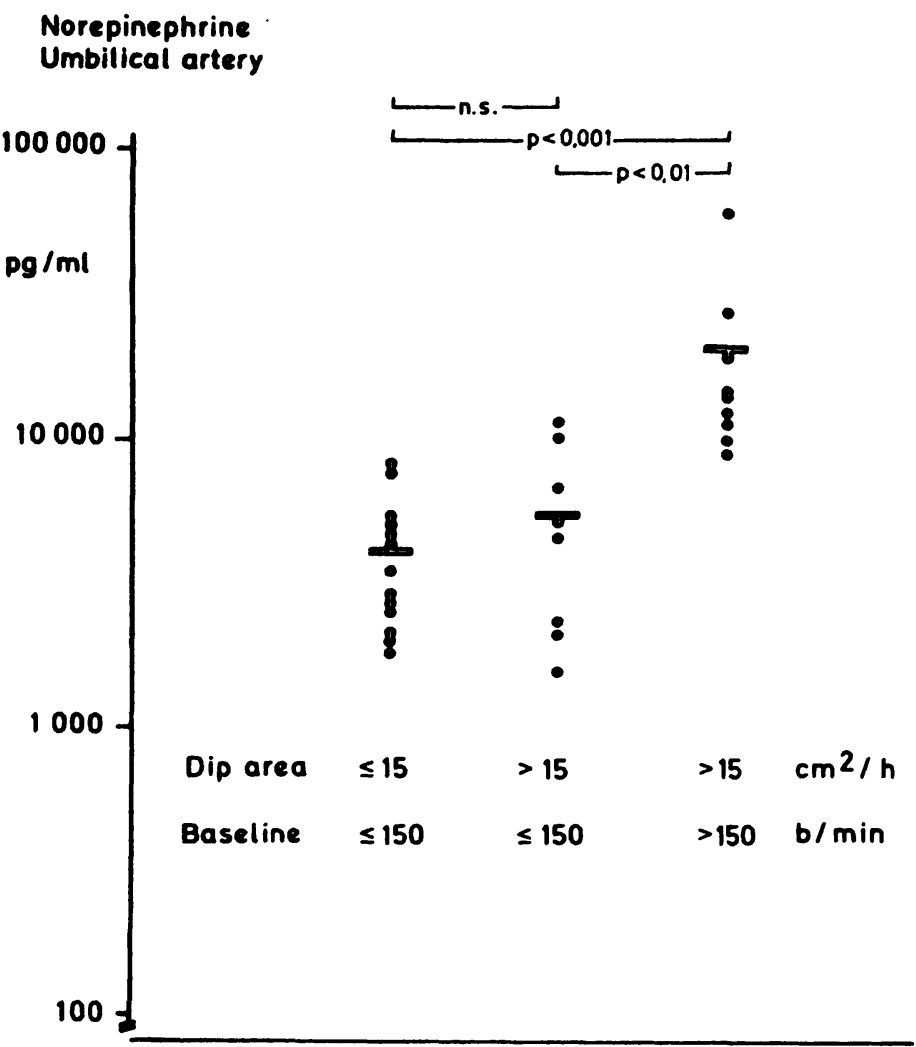

Fig. 7. Correlation between NE concentrations in the umbilical artery and alterations of the FHR. Alterations of the FHR are subdivided into deceleration area $\left(\leqslant\right.$ or $\left.>15 \mathrm{~cm}^{2} / \mathrm{h}\right)$ and baseline $(\leqslant$ or $>150 \mathrm{~b} / \mathrm{min}$ ). An increase of the deceleration area without tachycardia is not associated with a rise of NE levels. Only with additional tachycardia, which often coincides with a loss of oscillation amplitude, a significant increase of fetal arterial NE levels can be observed.

dent on the NE concentration in the fetal arterial blood (Fig. 10) and was found to increase with rising NE concentration.

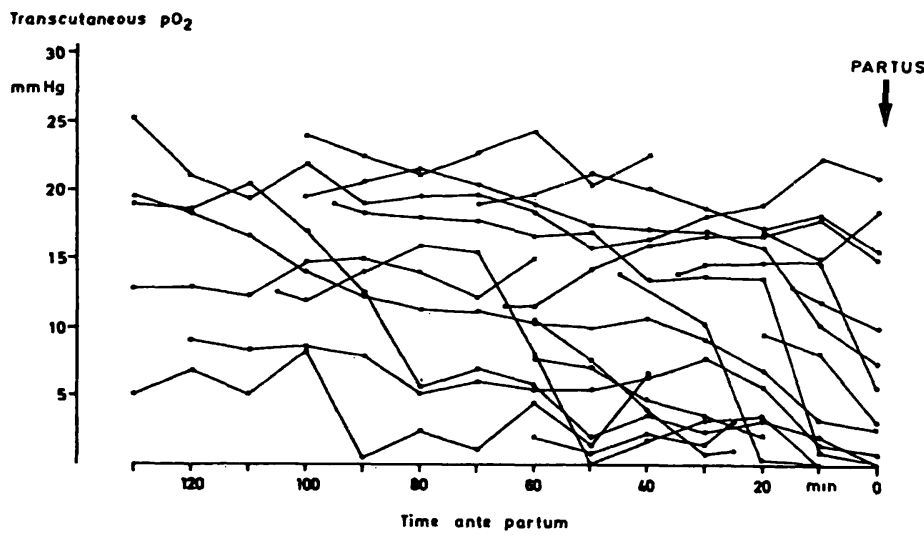

Fig. 8. Course of $\mathrm{tcpO}_{2}$ during the last two hours before delivery. $t \mathrm{cpO}_{2}$ values vary between 0 and $25 \mathrm{mmHg}$. In some cases a high $\mathrm{tcpO}_{2}$ is recorded until delivery, while a fall in $\mathrm{tcpO}_{2}$ can be demonstrated in other cases. 


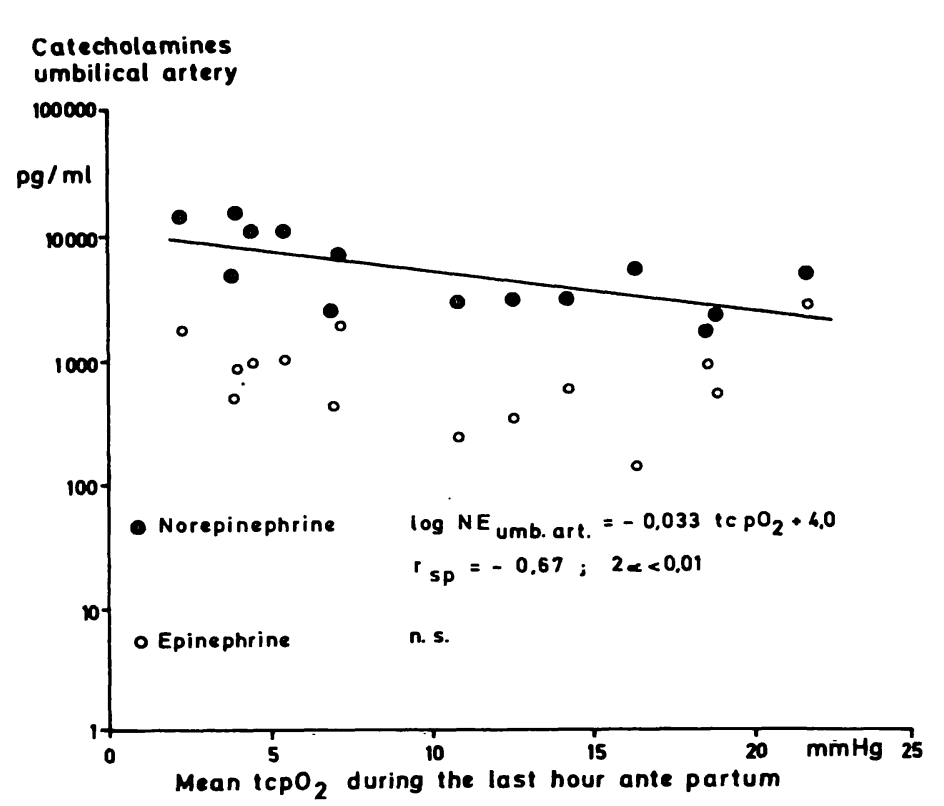

Fig. 9. Correlation between $\mathrm{tcpO}_{2}$ in the last hour before delivery and $\mathrm{NE}$ and $\mathrm{E}$ concentrations in the umbilical artery. There is a significant inverse relationship: $t c \mathrm{O}_{2}$ decreases with increasing NE.

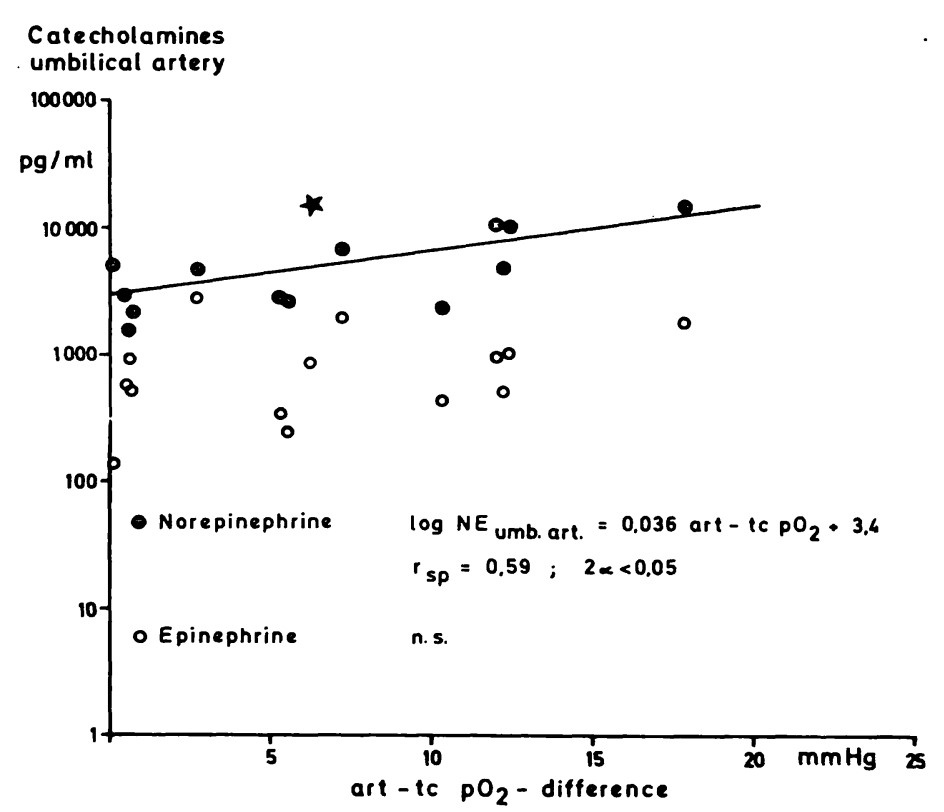

Fig. 10. Correlation between tc-art $\mathrm{pO}_{2}$-d in the last hour before delivery and $\mathrm{NE}$ and $\mathrm{E}$ concentrations in the umbilical artery. With rising NE-secretion the tc-art $\mathrm{pO}_{2}-\mathrm{d}$ increases. The correlation coefficient improved considerably after eliminating the value marked with an asterisk $\left(r_{s p}=0.74, p<0.01\right)$. This was the only patient exhibiting low umbilical artery $\mathrm{pO}_{2}(10.1 \mathrm{mmHg})$ at low oxygen saturation $(<20 \%)$.

\section{Discussion}

4.1 Catecholamine extraction by the placenta: The fetal artery NE and E concentrations were in part excessively high, mean values being four times higher than in the umbilical vein and exceeding those in the maternal venous blood 20 -fold for NE, and 10-fold for E (Fig. 1). These findings suggest that the catecholamines measured in cord blood are of fetal origin and that the placenta has a high capacity for inactivation of free catecholamines. At concentrations below $4000 \mathrm{pg} / \mathrm{ml}$ for $\mathrm{E}$ and $74,000 \mathrm{pg} / \mathrm{ml}$ for $\mathrm{NE}$, a saturation of the placental catecholamine extraction was not detectable (Fig. 3).

It appears that the high placental catecholamine clearance is primarily attributable to metabolization of biogenic amines. Studies with radioactively labelled tracers have shown that the placental transfer accounts for only $5-10 \%$ of the umbilical arteriovenous concentration difference [24, 31]. The enzymes catechol o-methyltransferase and monoamine oxidase, which are required for degradation of circulating catecholamines, have been demonstrated in placental tissue in high concentrations [5]. It also is probable that the biologic catecholamine inactivation is additionally effected by sulfate conjugation. Phenolsulfotransferase (EC 2.8.2.1), which is necessary for the conversion of free catecholamines to sulfated derivates has been isolated from human placental tissue [32].

Whereas umbilical artery $\mathrm{E}$ and NE concentrations were widely different, the extraction rates from the placenta with mean values of $75 \%$ were found to be identical (Fig. 2). This was to be anticipated since the metabolic pathways of $\mathrm{NE}$ and $\mathrm{E}$ are identical. However, a comparison of the placental $\mathrm{NE}$ and $\mathrm{E}$ extraction with that of other organs revealed that the placental tissue occupies a unique position: on passage of catecholamines through the liver, cardiac and skeletal muscle, the NE extraction rate is invariably lower than that of $E[4,13]$. The NE concentrations in the renal vein but also in the coronary sinus may even substantially exceed those measured in the arterial (afferent) blood $[21,26]$. These observations suggest that in tissues with abundant sympathetic innervation NE is not only extracted but may also be released from postganglionic sympathetic nerve endings $[21,26]$. As 
a circulating hormone, $\mathrm{E}$ in contrast is released only from the adrenal medulla (and some brain areas) and extracted on its passage through the other organs. Hence, the different extraction rates of $\mathrm{NE}$ and $\mathrm{E}$ may be taken to reflect the density of sympathetic innervation and the sympathetic activity of an organ other than the adrenal medulla $[4,13,21,26]$. In agreement with morphologic studies [30], the nearly identical placental extraction rates of $\mathrm{NE}$ and $\mathrm{E}$ indicate that sympathetic innervation is absent on the fetal side of the placenta.

4.2 Catecholamines and fetal hypoxia: Animal studies $[6,7,16,17,19]$ and clinical investigations $[2,3,10,18,20,25]$ suggest that fetal hypoxic shock is associated with vigorous sympathoadrenal stimulation, as reflected by an increase in circulating catecholamines, especially in NE. This concept receives further support from the results reported in the present paper. The finding that stimulation of NE secretion is frequently accompanied by fetal hypoxia is in accord with the observations of KANEOKA et al. [18] and LAGERCRANTZ et al. [20]. The rise of the arterial E concentration is distinctly less pronounced and less constant. The average arterial concentration of free $D$ is increased only 2.5 -fold over maternal blood levels. It thus becomes obvious that D hardly responds to sympathoadrenal system stimulation.

Both pathologic alterations in FHR (decelerations, tachycardia) and hypoxic acidosis/postpartum depression are associated with increased arterial $\mathrm{NE}$ concentration. Various investigators have reported that analogous correlations exist between catecholamines, acid-base balance $[2,10,18,20]$, and the APGAR score $[18,25]$. The results on FHR alterations and catecholamines are in part conflicting $[2,18,20]$. Unlike BISTOLETTI et al. [2], but in agreement with KANEOKA et al. [18], the present study evidences a quantitative relationship between the deceleration area and the arterial catecholamine levels (Fig.6). More differentiated analysis of the deceleration areas reveals that an increase of the deceleration area exceeding $15 \mathrm{~cm}^{2} / \mathrm{h}$ taken by itself is not associated with a rise in arterial NE (Fig. 7). It is only when an enlarged deceleration area coincides with fetal tachycardia that the NE concentration will increase substantially.

The findings in this study provide a differentiated confirmation of the relationship which exists, according to LAGERCRANTZ et al. [20], between a tachycardic baseline FHR and total catecholamines in the umbilical artery: Our observation that an increased baseline FHR is accompanied by a rise of both $\mathrm{NE}$ and $\mathrm{E}$ concentrations (Fig.6) supports the concept that the development of tachycardia may reflect a circulatory compensation for acute changes in the blood oxygen content, as manifested by the hypoxic shock syndrome.

The above results suggest that decelerations signalling acute changes in fetal arterial $\mathrm{pO}_{2}$ [19] cannot be taken to indicate the presence of a hypoxic shock syndrome with increased catecholamines merely on the strength of a quantitative analysis of the frequency, depth and duration of decelerations. Based on the available results, tachycardia should be evaluated as a supplementary parameter in the detection of fetal hypoxic shock.

There is no way of assessing to which extent other CTG features (e.g. loss of oscillation amplitude) can be employed as an indication of severe fetal hypoxia due to the heterogeneity of the CTG changes and the small number of tracings showing loss of oscillation without tachycardia.

4.3 Catecholamines, transcutaneous $\mathrm{pO}_{2}$, and transcutaneous-arterial $\mathrm{pO}_{2}$ difference: The results obtained on measurement of the tcpO $\mathrm{P}_{2}$ as described by $\mathrm{HUCH}$ [14] for intrapartum fetal monitoring are contradictory. Some authors reported good agreement between fetal arterial and transcutaneous $\mathrm{pO}_{2}$ levels [11]. However, when pathological CTG alterations occur, $t c \mathrm{O}_{2}$ values are frequently lower than the $\mathrm{pO}_{2}$ determined in arterialized fetal scalp blood [1, 15, 35]. In our studies, the $t c \mathrm{pO}_{2}$ recorded during the two hours prior to delivery, varied between 0 and $25 \mathrm{~mm} \mathrm{Hg}$ (Fig. 8). In the majority of cases, the $\mathrm{tcpO}_{2}$ was lower than the arterial $\mathrm{pO}_{2}$. Decreased $t c \mathrm{pO}_{2}$ levels with development of a transcutaneousarterial $\mathrm{pO}_{2}^{\circ}$ difference (tc-art $\mathrm{pO}_{2}$-d) were primarily seen with pathologic CTG changes. 
What then is the explanation for this tc-art $\mathrm{pO}_{2}-\mathrm{d}$ ? Besides the epidermal thickness and possible measuring artifacts (e.g. pressure exerted on the electrode), the cutaneous blood flow is a major factor determining the results of $\mathrm{tcpO}_{2}$ measurements. The $t c \mathrm{PO}_{2}$ only corresponds to the arterial $\mathrm{pO}_{2}$ when maximal vasodilatation, by warming the skin under the electrode to $42-43^{\circ} \mathrm{C}$ with the heating element of the electrode, is achieved [12, $14,27,34]$. Animal experiments have shown that the tcpO $\mathrm{O}_{2}$ varies from the arterial $\mathrm{pO}_{2}$ after recurrent hypoxic episodes. It appears that vasoconstriction of cutaneous vessels due to increased release of NE during hypoxia may be responsible for the observed tc-art $\mathrm{pO}_{2}$-d $[6,7,16,17]$. The heating element of the electrode obviously is not always capable of maintaining optimal cutaneous blood flow. This assumption receives further support from the fall in tcpO $\mathrm{O}_{2}$ observed after injection of $\mathrm{NE}$ into experimental animals, the $\mathrm{pO}_{2}$ in the arterial blood however remaining uneffected $[19,28]$.

In the present study, proof was furnished that in the human fetus hypoxic release of NE is closely correlated with the tcpO $\mathrm{O}_{2}$ in that $\mathrm{NE}$ levels rise with decreasing $\mathrm{tcpO}_{2}$ (Figs. 9, 10). Stimulation of the sympathoadrenal system in hypoxic episodes causes peripheral vasoconstriction with pallor as it occurs in severely depressed neonates (so-called "pale asphyxia").

From a theoretical point of view, the relationship between $\mathrm{NE}$ and the tc-art $\mathrm{pO}_{2}$-d should actually be nonlinear. The tc-art $\mathrm{pO}_{2}$-d, which is low when $\mathrm{NE}$ levels are low, shows an initial increase with rising NE; with the appearance of severe hypoxia and a further increase in NE, the arterial $\mathrm{pO}_{2}$ likewise starts to decrease. In the presence of severe hypoxia and a low arterial $\mathrm{pO}_{2}$, the tc-art $\mathrm{pO}_{2}$-d should consequently decrease again. This situation is depicted in Fig. 10 which shows considerable improvement of the correlation coefficient after elimination of one measuring point with an oxygen saturation below $20 \%$.

The established correlation between fetal arterial $\mathrm{NE}$ levels and the fall in $\mathrm{tcpO}_{2}$ lends additional support to the concept of KÜNZEL and JENSEN who had pointed to the potential of tcpO $\mathrm{O}_{2}$ monitoring in the diagnosis of a fetal hypoxic shock syndrome. These authors had shown that an increase in tc-art $\mathrm{pO}_{2}-\mathrm{d}$, together with the time interval during which a 'low tcpO $\mathrm{O}_{2}(0-3 \mathrm{~mm} \mathrm{Hg}$, the so-called "zero time") is recorded, are useful diagnostic tools in the detection of fetal shock [15]. On the other hand, it should be born in mind that even in the presence of a greatly reduced $\mathrm{tcpO}_{2}$ the central artery $\mathrm{pO}_{2}$, and hence the oxygen supply to vital organs unaffected by peripheral constriction (brain, heart, adrenal medulla), may not show a corresponding significant decrease. Also, there is a lack of exhaustive information as to which extent artifacts may affect the accuracy of transcutaneous monitoring (e.g. reduction in skin perfusion due to caput succedaneum or pressure exerted by the birth canal on the electrode).

\section{Clinical consequences to be considered in the diagnosis of fetal hypoxic shock syndrome at time of delivery}

For the obstetrician, the early detection of protracted fetal hypoxia as manifested by increased $\mathrm{NE}$ secretion, circulatory centralization, severe tissue hypoxia, and acidosis is of critical importance. While the diagnosis of acute fetal hypoxia presenting as continuous deceleration does not cause difficulty, the detection of hypoxic shock presenting as contraction-dependent decelerations poses a greater problem.

Based on the established interrelationship between increased catecholamine (NE) secretion and the various diagnostic parameters employed in intrapartum monitoring of the fetus, the diagnosis of hypoxic fetal shock syndrome is warranted if the following patterns are observed:

- wide and deep decelerations with an increased dip area and concurrent tachydardia

- severe metabolic acidosis of the fetus

- a greatly depressed tcpO ${ }_{2}$ that has fallen to a few $\mathrm{mm} \mathrm{Hg}$ (excepting artifacts)

The described investigations do not provide an answer as to how long fetal intrapartum hypoxia can be allowed to persist without creating a risk of late sequelae. Infants showing signs of extreme acidosis with concurrent release of catecholamines should therefore have a thorough follow-up. 


\section{Summary}

In 34 parturient women the levels of free epinephrine $(E)$, norepinephrine (NE), and dopamine (D) were determined by a radioenzymatic method using maternal venous and umbilical arterial and venous blood. The study was conducted to investigate the relationship between fetal catecholamines and hypoxia, fetal heart rate (FHR), and transcutaneous $\mathrm{pO}_{2}\left(\mathrm{tcpO} \mathrm{O}_{2}\right)$. The placental catecholamine extraction rates were also calculated.

\section{Results}

1. The $\mathrm{NE}$ concentrations $(10,200 \mathrm{pg} / \mathrm{ml})$ and the $\mathrm{E}$ concentrations $(1,120 \mathrm{pg} / \mathrm{ml})$ in the fetal arterial blood were highly elevated with mean values increased 4-fold over umbilical vein values. Compared with the maternal venous blood, $\mathrm{NE}$ values were increased 20 -fold and $E$ values 10 -fold (Fig. 1). Free $D$ concentrations in fetal arterial blood $(130 \mathrm{pg} / \mathrm{ml})$ had risen 2.5 -fold over maternal levels.

These results suggest that the catecholamines measured in cord blood are of fetal origin and that the placenta has a high capacity for inactivation of free catecholamines. The placental extraction rate is $77 \pm 14 \%$ for NE, $76 \pm 16 \%$ for $E$, and $33 \pm 25 \%$ for $D$ (Fig. 2). The placental extraction rates for $E$ and NE were virtually identical; in agreement with morphological studies they demonstrated absence of sympathetic innervation on the fetal side of the placenta.

2. Highly significant correlations were found between fetal arterial NE concentrations and the 1-minute APGAR score, pH and base deficit in the umbilical artery and alterations of the FHR (deceleration area, baseline FHR) (Figs. 4-6). Further analysis of FHR alterations (Fig. 7) reveals that an increase in deceleration area without tachycardia is not correlated with an increase of fetal arterial NE concentration. A signifi- cant rise in NE was only found with additional tachycardia which is often associated with a loss of oscillation aplitude.

Fetal arterial E concentrations were found to correlate with the fetal parameters indicating increased adrenal secretion of the hormone during fetal stress. However, correlation coefficients were lower than those obtained for NE (Figs. 4-6). A significant effect of fetal hypoxia on arterial and venous $D$ levels could not be demonstrated.

3. Fetal $\mathrm{tcpO}_{2}$ varies between $0-25 \mathrm{~mm} \mathrm{Hg}$ during the last two hours before delivery (Fig. 8). In most cases $\mathrm{tcpO}_{2}$ was lower than the arterial $\mathrm{pO}_{2}$. Besides epidermal thickness and artifacts, skin perfusion is a major factor influencing the $t \mathrm{cpO}_{2}$ (transcutaneous arterial $\mathrm{pO}_{2}$ difference). Vasoconstriction of the cutaneous vessels induced by increased $\mathrm{NE}$ secretion during hypoxia may obviously produce a fall in tcpO $\mathrm{O}_{2}$. This hypothesis receives support from the demonstration that the $t \mathrm{cpO}_{2}$ is correlated with the fetal arterial $\mathrm{NE}$ concentration: $\mathrm{tcpO}_{2}$ falls with rising $\mathrm{NE}$ and the tc-art $\mathrm{pO}_{2}$-d increases (Figs. 9-10). The stimulation of the sympathoadrenal system during hypoxia results in peripheral vasoconstriction as manifested by the pallor of depressed neonates ("white asphyxia").

\section{Clinical consequences}

In view of the demonstrated correlation between increased catecholamine (NE) secretion and the various parameters for monitoring fetal intrapartum conditions, fetal hypoxic shock can be taken to be present if

- wide and deep decelerations with an increased dip area occur in combination with tachycardia,

- severe fetal metabolic acidosis is present,

- $\mathrm{tcpO}_{2}$ is lowered to a few $\mathrm{mm} \mathrm{Hg}$ (excluding artifacts).

Keywords: Cardiovascular system, catecholamines, dopamine, epinephrine, extraction rate, fetal heart rate, fetal shock, norepinephrine, transcutaneous $\mathrm{pO}_{2}$, transcutaneous-arterial $\mathrm{pO}_{2}$ difference.

\section{Zusammenfassung}

Katecholamine im arteriellen und venösen Nabelschnurblut: plazentare Extraktion, Beziehungen zur fetalen Hypoxie und zum transkutanen Sauerstoffpartialdruck Bei 34 Gebärenden wurden im matern-venösen sowie arteriellen und venösen Nabelschnurblut die freie Adrenalin-(E), Noradrenalin-(NE) und Dopaminkonzentration (D) radioenzymatisch im Plasma bestimmt, um den Zusammenhang $z$ wischen fetaler Katecholaminkonzentration, Hypoxie, fetalen Herzfrequenzveränderungen und transkutanen $\mathrm{pO}_{2} \mathrm{zu}$ untersuchen und die plazentare Katecholaminextraktion zu bestimmen.

\section{Ergebnisse}

1. Im fetal arteriellen Blut finden sich zum Teil exzessiv erhöhte NE-(10 $200 \mathrm{pg} / \mathrm{ml})$ - und E-Konzentrationen $(1120 \mathrm{pg} / \mathrm{ml})$, die im Mittel 4 fach höher als in der $\mathrm{V}$. umbilicalis und beim NE 20fach und beim $E 10$ fach höher liegen als im mütterlichen venösen Blut (Abb.1). Das zirkulierende freie $D(130 \mathrm{pg} / \mathrm{ml})$ ist im fetalarteriellen Blut um das 2,5fache gegenüber dem mütterlich venösen erhöht. Diese Befunde sprechen dafür, daß die im Nabelschnurblut gemessenen Katecholamine fetalen Ursprungs sind und die Plazenta eine hohe Kapazität zur Inaktivierung von freien Katecholaminen aufweist. Die plazentare Extraktionsrate beträgt für $\mathrm{NE} 77 \pm 14 \%$, für $\mathrm{E} 76 \pm 16 \%$ und für D $33 \pm 25 \%$ (Abb. 2). Die bei der Plazentapassage gefundenen nahezu gleichen Extraktionsraten für $E$ und NE weisen in Übereinstimmung mit morphologischen Studien darauf hin, daß in der Plazenta keine sympathische Nervenversorgung vorhanden ist.

2. Zwischen der NE-Konzentration in der A. umbilicalis und dem APGAR (nach 1 Minute), dem pH und Basendefizit in der $A$. umilicalis sowie den Veränderungen der FHF (Dezelerationsfläche, basale Herzfrequenz) bestehen hochsignifikante Korrelationen (Abb.4-6). Die nähere Analyse der FHF-Veränderungen zeigt (Abb.7), daß eine Zunahme der Dezelerationsfläche allein ohne Tachykardie nicht mit einem Anstieg der NE-Konzentration korreliert. Erst bei zusätzlichem Auftreten einer Tachykardie, die zumeist 
mit einer Einschränkung der Oszillationsamplitude einhergeht, ist ein signifikanter NE-Anstieg nachweisbar. Für die E-Konzentrationen in der A. umbilicalis als Ausdruck der gesteigerten adrenalen Freisetzung des Hormons bei Streßzuständen lassen sich ebenfalls Korrelationen zu den fetalen Parametern nachweisen; die Korrelationskoeffizienten liegen jedoch niedriger als dies für NE zutrifft (Abb.4-6). Die fetale Hypoxie hat auf die arteriellen und venösen $D$-Spiegel indessen kaum einen Einfluß.

3. Der $t c \mathrm{O}_{2}$ schwankt in den letzten beiden Stunden vor der Geburt zwischen 0 und $25 \mathrm{mmHg}$ (Abb. 8). In den meisten Fällen liegt der $\mathrm{tcpO}_{2}$ niedriger als der arterielle $\mathrm{pO}_{2}$ (arterielle-transkutane $\mathrm{pO}_{2}$-Differenz). Der $\mathrm{tcpO}_{2}$ ist neben der Epidermisdicke und möglichen Meßartefakten (z. B. Druck auf die Elektrode) im wesentlichen abhängig von der Hautdurchblutung. Offensichtlich kann eine Vasokonstriktion der Hautgefäße, bedingt durch NE-Freisetzung während der Hypoxie, zu einem tcpO $\mathrm{O}_{2}$-Abfall führen. Dafür spricht, daß zwischen hypoxisch bedingter NE-Ausschüttung und dem $\mathrm{tcpO}_{2}$ eine enge Korrelation vorhanden ist: bei steigender NE-Konzentration fällt der $\operatorname{tcpO}_{2} a b$ und die arterielle-transkutane $\mathrm{pO}_{2}$-Differenz nimmt $\mathrm{zu}$ (Abb. 9, 10). Die Stimulation des sympathoadrenalen Systems bei-Hypoxie führt zu einer peripheren Vasokonstriktion, die zu der bei schwer deprimierten Neugeborenen bekannten Hautblässe führt (sogenannte „blasse Asphyxie").

\section{Klinische Schlußfolgerungen}

Aufgrund des gesicherten Zusammenhangs zwischen erhöhter Katecholamin- (besonders NE)-Sekretion und den verschiedenen diagnostischen Hypoxieparametern der fetalen Intensivïberwachung ist ein hypoxischer Schockzustand des Feten anzunehmen, wenn

- breite und tiefe Dezelerationen mit großer Dezelerationsfläche in Kombination mit Tachykardie,

- eine schwere metabolische Azidose des Feten,

- ein auf wenige $\mathrm{mmHg}$ erniedrigter $\mathrm{tcpO}_{2}$ (Artefakte ausgeschlossen)

vorliegen.

Schlüsselwörter: Adrenalin, Dopamin, Extraktionsrate, fetale Herzfrequenz, fetaler Schock, kardiovaskuläres System, Katecholamine, Noradrenalin, transkutan-arterielle $\mathrm{pO}_{2}$-Differenz, transkutaner $\mathrm{pO}_{2}$.

\section{Résumé}

Catécholamines chez la parturiente, dans le sang veineux maternel et dans le sang ombilical artériel et veineux On a déterminé les taux d'Adrénaline libre (A), de Noradrénaline (NA) et de Dopamine (D) par une méthode radioenzymatique chez 34 parturientes, dans le sang veineux maternel, et dans les sangs veineux et artériel ombilicaux. Cette étude a été réalisée afin de rechercher la relation entre les catécholamines fœtales et l'hypoxie, le rythme cardiaque fœtal (RCF) et la $\mathrm{pO}_{2}$ transcutanée $\left(\mathrm{pO}_{2} \mathrm{tc}\right)$. On a aussi calculé le taux d'extraction des catécholamines placentaires.

\section{Résultats}

1. Les concentrations de $\mathbf{N A}(10,200 \mathrm{pg} / \mathrm{ml})$ et de $\mathbf{A}$ $(1,120 \mathrm{pg} / \mathrm{ml})$ du sang artériel fœtal sont très élevées avec une augmentation de plus de 4 fois des valeurs moyennes par rapport aux valeurs de la veine ombilicale. Comparées aux valeurs du sang veineux maternel, les valeurs de NA sont augmentées de 20 fois, et les valeurs de $A$ de 10 fois (Fig. 1). Les concentrations de D libre dans le sang artériel fœtal $(130 \mathrm{pg} / \mathrm{ml})$ sont élevées 2,5 fois au dessus des taux maternels.

Ces résultats suggèrent que les catécholamines mesurées dans le sang du cordon sont d'origine fœtale et que le placenta a une capacité élevée d'inactivation des catécholamines libres. Le taux d'extraction placentaire est de $77 \pm 14 \%$ pour la nor-adrénaline, de $76 \pm 16 \%$ pour l'adrénaline, et de $33 \pm 25 \%$ pour la D (Fig. 2). Les taux d'extraction placentaire sont virtuellement identiques pour l'adrénaline et la nor-adrénaline; en accord avec les études morphologiques, ces résultats démontrent l'absence d'innervation sympathique au niveau de la face fœtale du placenta.

2. On a trouvé des corrélations hautement significatives entre les concentrations artérielles fœtales de NA et le score d'APGAR à une minute, le pH et le base déficit artériel ombilical, et les altérations du RCF (surface de décélération, rhythme de base) (Fig.4-6). En outre, l'analyse deș altérations du RCF (Fig. 7) met en évidence qu'une augmentation des surfaces de décélérations sans tachycardie n'est pas corrélée avec une augmentation artérielle fœtale de NA. Une élévation significative de NA n'a été trouvée qu'avec une tachycardie surajoutée, tachycardie souvent accompagnée d'une perte de l'amplitude des oscillations.

On a trouvé que les concentrations artérielles fœtales d'A sont corrélées avec les paramètres fœtaux indiquant une sécrétion surrénalienne hormonale augmentée au cours du stress fœtale. Toutefois, les coefficients de corrélation sont plus faibles que ceux obtenus pour la NA (Fig.4-6). On n'a pas pu démontrer d'effet significatif de l'hypoxie fœtal sur les niveaux artériels et veineux de $D$.

3. $\mathrm{La} \mathrm{pO}_{2}$ tc varie de 0 à $25 \mathrm{~mm}$ de $\mathrm{Hg}$ pendant les deux dernières heures qui précèdent l'accouchement (Fig. 8). Dans de nombreux cas la $\mathrm{pO}_{2}$ tc est plus basse que la $\mathrm{pO}_{2}$ artérielle. A côté de l'épaisseur de l'épiderme et des artefacts, la perfusion cutanée est un facteur majeur influençant la $\mathrm{pO}_{2}$ tc (différence de la $\mathrm{pO}_{2}$ artérielle transcutanée). La vasoconstriction des vaisseaux cutanés induite par une élévation de la sécrétion de NA au cours de l'hypoxie peut entraîner objectivement une chute de la $\mathrm{pO}_{2}$ tc.

Cette hypothèse est renforcée par la démonstration que la $\mathrm{pO}_{2}$ tc est corrélée avec la concentration artérielle fœtale de NA: la $\mathrm{pO}_{2}$ tc diminue lors de l'augmentation de $\mathrm{NA}$ et la $\mathrm{pO}_{2}$ tc artérielle augments (Fig. 9-10). La stimulation du système sympathique pendant l'hypoxie entraine une vasoconstriction 
périphérique, vasoconstriction dont témoigne la pâleur des nouveaux-nés déprimús («asphyxie planche»).

\section{Conséquences cliniques}

Dans l'optique de la corrélation démontrée entre l'augmentation de la sécrétion de catécholamines (NA) et les divers paramètres de la surveillance du fœtus en cours de travail, on peut considérer qu'il existe un choc fœtal hypoxique si:

- surviennent des décélérations larges et profondes avec une augmentation des surfaces de décélérations, accompagnées d'une tachycardie;

- il existe une acidose métabolique fœtale sévère;

- la $\mathrm{pO}_{2}$ tc s'abaisse à quelques $\mathrm{mm}$ de $\mathrm{Hg}$ (en dehors de tout artefact).

Mots-clés: Adrénaline, catécholamines, choc fœtal, différence de $\mathrm{la}_{\mathrm{pO}} \mathrm{O}_{2}$ artérielle transcutanée, dopamine, nor-adrénaline, $\mathrm{pO}_{2}$ transcutanée, rythme cardiaque fœtal, système cardio-vasculaire, taux d'extraction.

\section{Bibliography}

[1] BAXI, L., L. S. JAMES: Validity of transcutaneous $\mathrm{pO}_{2}$ in human fetus. Second International Symposium on Continuous Transcutaneous Blood Gas Monitoring, Zürich 1981. Dekker, New York and Basel, in press.

[2] Bistoletti, P., H. Lagercrantz, N. O. LUNELL: Correlation of fetal heart rate pattern with umbilical artery $\mathrm{pH}$ and catecholamines during last hour of labor. Acta Obstet. Gynec. Scand. 59 (1980) 213

[3] BLOUQUIT, M. F., G. STURBOIS, G. BREAT et al.: Catecholamine levels in newborn human plasma in normal and abnormal conditions and in maternal plasma at delivery. Experimentia 35 (1979) 618

[4] BROWN, M. J., D. A. JENNER, D. J. ALLISON et al.: Variations in individual organ release of noradrenaline measured by an improved radioenzymatic technique; limitations of peripheral venous measurements in the assessment of sympathetic nervous activity. Clin. Sci. 61 (1981) 585

[5] CASTREN, O., S. SAARIKOSKI: The simultaneous function of catechol-0-methyltransferase and monoamine oxidase in human placenta. Acta Obstet. Gynec. Scand. 53 (1974) 41

[6] COHN, H. E., E. SACKS, M. A. HEYMANN et al.: Cardiovascular response to hypoxemia and acidemia in fetal lambs. Am. J. Obstet. Gynec. 120 (1974) 817

[7] COMLiNe, R. S., J. A. SilveR, M. SilveR: Factors responsible for the stimulation of the adrenal medulla during asphyxia in the foetal lamb. J. Physiol. 178 (1965) 211

[8] DA PRADA, M., G. S. ZÜRCHER: Simultaneous radioenzymatic determination of plasma and tissue adrenaline, noradrenaline and dopamine within the femtomole range. Life Sci. 19 (1976) 1161

[9] ELIOT, J. R., R. LAM, R. D. LEAKE et al.: Plasma catecholamine concentrations in infants at birth and during the first 48 hours of life. Pediatrics 96 (1980) 311

[10] FALCONER, A. D., D. M. LAKE: .Circumstances influencing umbilical-cord plasma catecholamines at delivery. Br. J. Obstet. Gynec. 9 (1982) 44

[11] FALL, O., M. JOHNSSON, B. A. NILSSON et al.: A study of the correlation between the oxygen tension of the fetal scalp blood and the continuous, transcutaneous oxygen tension in human fetuses during labour. In: HUCH, A., R. HUCH, J. F. LUCEY: Continuous Transcutaneous Blood Gas Monitoring. Original Article Series - Birth Defects The National Foundation March of Dimes, Vol. 15, 4 A. R. Liss. Inc., New York 1979

[12] FALL, O., B. EK, B. A. NILSSON et al.: The effects of mechanical pressure and local stasis on transcutaneous monitoring of fetal oxygen tension. Br. J. Obstet. Gynaec. 87 (1980) 230

[13] HENRIKSEN, J., N. J. CHRISTENSEN, H. RINGLARSEN: Noradrenaline and adrenaline concentrations in various vascular beds in patients with cirrhosis. Relation to hemodynamics. Clinical Physiology 1 (1981) 293

[14] HUCH, R., A. HUCH, D. W. LÜBBERS: Transcutaneous measurement of blood $\mathrm{pO}_{2}\left(\mathrm{tcpO}_{2}\right)$-method and application in perinatal medicine. J. Perinat. Med. 1 (1973) 183

[15] JENSEN, A., W. KÜNZEL: The difference between fetal transcutaneous $\mathrm{pO}_{2}$ and arterial $\mathrm{pO}_{2}$ during labour. Gynec. Obstet. Invest. 11 (1980) 249

[16] JENSEN, A., M. HOHMANN, W. KÜNZEL: Änderung der Organdurchblutung und des transkutanen $\mathrm{pO}_{2}$ des Feten nach rezidivierenden Hypoxien. Arch. Gynecol. 235 (1983) 646

[17] JONES, C. T., R. O. ROBINSON: Plasma catecholamines in fetal and adult sheep. J. Physiol. 248 (1975) 15

[18] KANEOKA, T., H. OZONO, U. GOTO et al.: Plasma noradrenalin and adrenalin concentrations in fetomaternal blood: Their relations to fetomaternal endocrine levels, cardiotocographic and mechanocardiographic values, and umbilical arterial blood biochemical profilings. J. Perinat. Med. 7 (1979) 302

[19] KÜNZEL, W., E. KASTENDIECK, C. S. KURZ et al.: Transcutaneous $\mathrm{pO}_{2}$ and cardiovascular observations in the sheep fetus following the reduction of uterine blood flow. J. Perinat. Med. 8 (1980) 85

[20] LAGERCRANTZ, H., P. BISTOLETTI: Catecholamine release in the newborn infant at birth. Pediatr. Res. 11 (1977) 889

[21] LEEUW, P., W. DE, H. E. FALKE et al.: Noradrenaline secretion by the human kidney. Clinical Science and Molecular Medicine 55 (1978) 85

[22] LEONETTI, G., C. BiANCHINI, G. B. PiCOTTI et al.: Plasma catecholamines and plasma renin activity at 
birth and during the first days of life. Clin. Sci. 59 (1980) 319

[23] MESSOW-ZAHN, K., M. SARAFOFF, K. P. RIEGEL: Stress at birth: Plasma noradrenaline concentrations of women in labour and in cord blood. Klin. Wochenschr. 56 (1978) 311

[24] MORGaN, D., M. SANDler, M. PANIGEL: Placental transfer of catecholamines in vitro and in vivo. Am. J. Obstet. Gynec. 112 (1972) 1068

[25] NAKAI, T., R. YAMADA: The secretion of catecholamines in newborn babies with special reference to fetal distress. J. Perinat. Med. 6 (1978) 39

[26] Oliver, J., J. PINTO, R. SCIACCA et al.: Basal norepinephrine overflow into the renal vein: effect of renal nerve stimulation. Am. J. Phyiol. 239 (1980) F 371

[27] PAULICK, R.: Der Einfluß der Epidermisdicke auf die transkutane $\mathrm{pO}_{2}$-Messung. $\mathrm{Z}$. Geburtsh. Perinat. 186 (1982) 82

[28] PAULICK, R., W. KÜNZEL: Der transkutane Sauerstoffpartialdruck beim Meerschweinchen - Untersuchungen zur Wirkung von Dextran 40, Hypoxie, Adrenalin und Noradrenalin. Z. Geburtsh. Perinat. 186 (1982) 269

[29] PEULER, J., G. JOHNSON: Simultaneous single isotope radioenzymatic assay of plasma norepinephrine, epinephrine and dopamine. Life Sci. 21 (1977) 625

[30] REILLY, F. D., P. T. RUSELL: Neurohistochemical evidence supporting an abscence of adrenergic and cholinergic innervation in the human placenta and umbilical cord. Anat. Rec. 188 (1977) 277

[31] SAARIKOSKI, S.: Fate of noradrenaline in the human foetoplacental unit. Acta Physiol. Scand. 93 (1975) Suppl. 421
[32] SCHNEIDER, H.: Zum Übergang von Medíkamenten von der Mutter auf den, Fet. Gynäkologe 15 (1982) 122

[33] SIGGAARD-ANDERSEN, O.: Therapeutic aspects of acid-base disorder. In: EVANS, F. T., T. C. GRAY: Modern Trends in Anaesthesia. Butterworths, London 1967

[34] WALLENBURG, H. C. S., A. VERHÖFF, T. C. JANSEN et al: Effects of external pressure on the fetal head on fetal transcutaneous $\mathrm{pO}_{2}\left(\mathrm{tcpO}_{2}\right)$ and arterial $\mathrm{pO}_{2}$ - an experimental study in sheep. Second International Symposium on Continuous Transcutaneous Blood Gas Monitoring, Zürich 1981. Dekker, New York and Basel, in press

[35] WEBER, T., N. J. SECHER: Transcutaneous fetal oxygen tension and fetal heart rate pattern preceding fetal death. Br. J. Obstet. Gynec. 87 (1980) 165

[36] WERNZE, H., P. DÜNNINGER, R. LAJT KEP: Radioenzymatic measurement of plasma catecholamines: pitfalls and improvements in methodology. In press

Received August 1, 1983. Revised September 14, 1983 Accepted October 18, 1983.
Dr. R. Paulick

Department of Gynecology

University of Wuerzburg

Josef-Schneider-Str. 4

D-8700 Wuerzburg, F. R. Germany 